\title{
Comparative Analysis of the in-vitro Susceptibility of Salmonella Typhi to Chloramphenicol and Leaf Extracts of Moringa Oleifera
}

\author{
Article by Oche Joseph Otorkpa \\ Usmanu Danfodiyo University, Sokoto State \\ E-mail: ochejoseph@yahoo.com
}

\begin{abstract}
The objective of this study was to compare the in-vitro susceptibility of clinical isolates of Salmonella typhi to Chloramphenicol and leaf extracts of Moringa oleifera. The in-vitro effects of both substances were evaluated using ethanol, ether, hot and cold water extracts of the plants leaf. The hot and cold water extracts showed no activity against the organism while the organism was sensitive to the ethanol and ether extracts at concentrations of 40,60,80, 100 , and $120 \mathrm{mg} / \mathrm{ml}$ with zones of inhibition $(\mathrm{mm})$ of 4.0, 4.0, 7.0, 9.0, 8.0and 4.0, 6.0, 7.0, 8.0, 8.0 respectively. The organism was also sensitive to two brands of chloramphenicol $A$ and $B$ with zones of inhibition 15.0, 13.0, 14.0, 23.0, and 25.0. 20.0, 18.0, 16.0, 21.0, and 20.0. Respectively at various concentrations. The findings from this study confirms that chloramphenicol has higher in-vitro activity against Salmonella typhias compared to the leaf extract of Moringa oleifera regardless of the method employed in the extraction process
\end{abstract}

Keywords: Salmonella typhi, Susceptibility, Leaf extracts, Medicinal plants, chloramphenicol, Moringa oleifera

\section{Introduction}

Salmonella typhi is a gram negative rod shaped motile non spore forming bacterium belonging to the f family Enterobacteriaceae, this facultative anaerobe is the causative agent of typhoid fever. morphologically it has 2 membranes (outer and an inner), periplasm, and a Lipopolysaccharide chain that consists of $\alpha$-d-galactosyl-( $\rightarrow$ 2)- $\alpha$-d-mannosyl-( $1 \rightarrow 4)-1-$ rhamnosyl-(1 $\rightarrow$ 3)-repeating units, and has short branches of single 3, 6-dideoxyhexose residues]

Humans become infected with Salmonella typhias a result of the ingestion of food or untreated water containing the organism. Once ingested they are taken up by the mononuclear phagocytes whose job it is to engulf and destroy the invading bacteria. However, in some cases the bacteria evade the phagocytes and multiply within the cells and spill into the blood stream where they produce symptoms of the disease. S, typhi is implicated in the death of over half a million people worldwide each year largely due to poor environmental and sanitary conditions especially in developing countries.

The organism is susceptible to a wide range of antibiotics and to date over 107 different strains of the organism have been isolated with different level of virulence, many of these strains have been reported to have complex metabolic features and multi-drug resistance genes that complicates treatment of typhoid fever especially in typhoid fever endemic areas.

Although native to India, Moringa oleifera is a widely distributed plant in Nigeria, it is extensively cultivated in different parts of the country, mainly in family gardens of northern Nigeria. The plant is an Angiosperms belonging to the Order Brassicales and Family Moringaceae. The plant can grow to a height of:10-12 meters, the leaves build up a feathery foliage of tripinnate leaves. The flowers are fragrant and bisexual, surrounded by five unequal, thinly veined, yellowish-white petals. The flowers are about 1.0-1.5 centimeters long and two centimeters broad. They grow on slender, hairy stalks in spreading or drooping later flower clusters which have a length of 10-25 centimeters.

In Africa, especially Sokoto Northwestern Nigeria the leaves and stem of M. oleifera is considered a delicacy and sold as snacks and a remedy for various ailments and infections. In 
other regions the leaves and other parts of the plant are extensively used for a wide variety of purposes due to its rich macro- and micronutrients content. Studies have reported that Moringa oleifera is a good source of vitamin C, Vitamin B, vitamin K and Beta carotene.

\section{Objective of the study}

The increasing level of multi drug resistance pattern and the tendency of salmonella typhi to alter its genotypic and phenotypic features in response to changes in the environment has made it increasing difficult to effectively execute measures that will eradicate the organism from the food chain, this necessitated a research to assess the in-vitro effect of different extracts of Moringa oleifera a widely used medicinal plant and food on the organism.

\section{Materials and method}

The samples were collected as described by Deeni and Aishatu (1994), Mohammed (1996) and Cheesbrough (2000).

\section{Sample collection}

Plant material were collected from local farms in Dundaye village near the permanent site of the Usmanu Danfodiyo University Sokoto, Nigeria. The plant was identified in the Botany unit of the Usmanu Danfodiyo University Sokoto .The leaves were plucked and sundried for two days and later grounded into powder using pestle and mortar. The powder was sieved with an eighty micron sized aperture. The chloramphenicol capsules were obtained from Freedom Pharmacy and French Afrique Pharmacy Sokoto

\section{Test organism}

The test organism (clinical isolates) were obtained from Microbiology laboratory of Usman Danfodiyo University Teaching Hospital, Sokoto.

\section{Processing of plant leaves}

\section{Extraction procedure}

\section{Cold water extract}

Two gram of the powder was weighed using a weighing balance and put into a beaker constraining one hundred milliliters $(100 \mathrm{ml})$ of distilled water left overnight. Similarly procedure was repeated for $3 \mathrm{~g}, 5 \mathrm{~g}, 10 \mathrm{~g}$, and $15 \mathrm{~g}$ of the powder the suspension was then filtered with funnel and cotton wool to obtain the extract. The extract was allowed to stand until the volume reduced to $10 \mathrm{ml}$.

\section{Hot water extract}

Two grams of the powder was weighed using a weighing balance and put into a beaker containing one hundred milliliter $(100 \mathrm{ml})$ of distilled water and boiled on a hot plate. The boiled suspension was then left overnight. The same procedure was carried out using $3 \mathrm{~g}, 5 \mathrm{~g}$, $10 \mathrm{~g}$, and $15 \mathrm{~g}$ of the powder, the suspension was then filtered using cotton wool and funnel. The extract was then concentrated to $10 \mathrm{ml}$ by boiling.

\section{Ethanol Extract}

Ten (10) gram of powder was weighed using a weighing balance. The powder was then dispense into thimble which was place in the soxhlet extractor containing two hundred milliliters (200ml) of the solvent (Ethanol).

The soxhlet extractor was then operated until colour change became visible indicating that the extraction process has commenced this continued until no further change in the colour of the solvent was visible and thus marked the end of the extraction process.

The ethanol was separated from the extract by heating and condensation of the ethanol into the extractor and collection of the extract in a $10 \mathrm{ml}$ beakers. The same procedure was repeated for $15 \mathrm{~g}, 20 \mathrm{~g}, 25 \mathrm{~g}$ and $30 \mathrm{~g}$ 


\section{Ether extract}

Ten (10) grams of the powder was weighed using a weighing balance. The powder was then dispensed into the thimble, which was then placed in the soxhlet extractor containing two hundred milliliters $(200 \mathrm{ml})$ of the solvent (ether). The soxhlet extractor was then operated until colour change became visible indicating the commencement of the extraction process.

This continued until there was no further change in colour of the solvent, which marked the end of the extraction process.

The ether was then separated from the extract by heating and condensation of ether into extractor and the collection of the extract in a $(10 \mathrm{ml})$ beaker.

The same procedure was repeated for $15 \mathrm{~g}, 20 \mathrm{~g}, 25 \mathrm{~g}$ and $30 \mathrm{~g}$

\section{Preparation of media}

The media were prepared according to manufacturer's specifications.

\section{Preparation of Disc}

Disc of about $6.0 \mathrm{~mm}$ in diameter were punched from what man filter paper No. 1 and sterilized in a hot air oven at 160 oc for 1 hour.

The antibiotics solutions were made using sterile distilled water. The disc were then put into the varying concentrations of the antibiotic solution and extract and allowed to soak all the liquid after which they were air dried.

\section{Sensitivity test}

Discs diffusion techniques was employed as described by chees borough (2000), Edward (1979), Lacey (1984), Deeni and Aishatu (1994).

\section{Results}

The cold water, hot water and ethanol of showed no activity in-vitro on clinical isolates of Salmonella typhi

Table 1. Shows the susceptibility of Salmonella typhi in zones of inhibition (mm) obtained against different concentrations of ethanol extract of Moringa oleifera

\begin{tabular}{|l|l|l|}
\hline $\begin{array}{l}\text { Concentration } \\
(\mathrm{mg} / \mathrm{ml})\end{array}$ & $\begin{array}{l}\text { Zones of } \\
\text { inhibition }(\mathrm{mm})\end{array}$ & Control \\
\hline 40 & 4 & $\begin{array}{l}\text { Chloramphenicol } \\
250 \mathrm{mg} / 25 \mathrm{ml}\end{array}$ \\
\hline 60 & 4 & $\begin{array}{l}\text { Chloramphenicol } \\
250 \mathrm{mg} / 25 \mathrm{ml}\end{array}$ \\
\hline 80 & 7.0 & $\begin{array}{l}\text { Chloramphenicol } \\
250 \mathrm{mg} / 25 \mathrm{ml}\end{array}$ \\
\hline 100 & 9.0 & $\begin{array}{l}\text { Chloramphenicol } \\
250 \mathrm{mg} / 25 \mathrm{ml}\end{array}$ \\
\hline 120 & 8.0 & $\begin{array}{l}\text { Chloramphenicol } \\
250 \mathrm{mg} / 25 \mathrm{ml}\end{array}$ \\
\hline
\end{tabular}

\section{Salmonella typhi}

Table 2. shows the susceptibility of Salmonella typhi in zones of inhibition (mm) obtained against different concentrations of ether extract of Moringa oleifera

\begin{tabular}{|l|l|l|}
\hline $\begin{array}{l}\text { Concentration }(\mathrm{mg} \\
/ \mathrm{ml})\end{array}$ & $\begin{array}{l}\text { Zones of inhibition } \\
(\mathrm{mm})\end{array}$ & Control \\
\hline 40 & 4.0 & Chloramphenicol \\
\hline
\end{tabular}


Texila International Journal of Medicine

Volume 5, Issue 1, Jun 2017

\begin{tabular}{|l|l|l|}
\hline & & $250 \mathrm{mg} / 25 \mathrm{ml}$ \\
\hline 60 & 6.0 & $\begin{array}{l}\text { Chloramphenicol } \\
250 \mathrm{mg} / 25 \mathrm{ml}\end{array}$ \\
\hline 80 & 7.0 & $\begin{array}{l}\text { Chloramphenicol } \\
250 \mathrm{mg} / 25 \mathrm{ml}\end{array}$ \\
\hline 100 & 8.0 & $\begin{array}{l}\text { Chloramphenicol } \\
250 \mathrm{mg} / 25 \mathrm{ml}\end{array}$ \\
\hline 120 & 8.0 & $\begin{array}{l}\text { Chloramphenicol } \\
250 \mathrm{mg} / 25 \mathrm{ml}\end{array}$ \\
\hline
\end{tabular}

The clinical isolates were highly susceptible to the antibiotic (chloramphenicol).

Table 3. Shows the susceptibility of Salmonella typhi in zones of inhibition (mm) obtained against different concentration of brand A of chloramphenicol.

\begin{tabular}{|l|l|}
\hline $\begin{array}{l}\text { Concentration } \\
(\mathrm{mg} / \mathrm{ml})\end{array}$ & Zones of inhibition (mm) \\
\hline $250 \mathrm{mg} / 10 \mathrm{ml}$ & 15.0 \\
\hline $250 \mathrm{mg} / 20 \mathrm{ml}$ & 13.0 \\
\hline $250 \mathrm{mg} / 30 \mathrm{ml}$ & 14.0 \\
\hline $250 \mathrm{mg} / 40 \mathrm{ml}$ & 23.0 \\
\hline $250 \mathrm{mg} / 50 \mathrm{ml}$ & 25.0 \\
\hline
\end{tabular}

The clinical isolates were also susceptible to Brand B of the antibiotic

Table 4. Shows the susceptibility of Salmonella typhi (zones of inhibition) (mm) obtained against different concentration of brand B of chloramphenicol

\begin{tabular}{|l|c|}
\hline $\begin{array}{l}\text { Concentration } \\
\text { (mg/ml) }\end{array}$ & Zones of inhibition (mm) \\
\hline $250 \mathrm{mg} / 10 \mathrm{ml}$ & 20.0 \\
\hline $250 \mathrm{mg} / 20 \mathrm{ml}$ & 18.0 \\
\hline $250 \mathrm{mg} / 30 \mathrm{ml}$ & 16.0 \\
\hline $250 \mathrm{mg} / 40 \mathrm{ml}$ & 21.0 \\
\hline $250 \mathrm{mg} / 50 \mathrm{ml}$ & 20.0 \\
\hline
\end{tabular}

\section{Discussion}

The results obtained from the study showed that chloramphenicol is still more effective in the management of infections as a result of Salmonella typhi than all the leave extracts of Moringa oleifera analyzed, as evidenced with the higher zones of inhibition $>20$ recorded for various concentration of the drug against those recorded for different extracts of the plant. This findings align with the set standards according to the National Committee for Clinical Laboratory Standards, NCCLS (1997).

Despite the wide spread report of increasing report of multi drug resistance in the management of infections due to salmonella typhi, it is evident from this study that chloramphenicol remains an important agent in the pharmacotherapy of typhoid fever, this also tarries with the recommendations of (Chandel 2000) which reported that the suggestions that quinolones i.e. ciprofloxacin as a remedy to the increasing incidence of resistance recorded in the management of typhoid fever should be reconsidered, as a result of the increasing susceptibility of the organism to chloramphenicol. They submitted that the development of resistance by salmonella typhi to ciprofloxacin is partly related to its exposures to concentrations near their minimum inhibitory concentration (MIC). With increases in MICs, clinicians may be tempted to administer higher doses of ciprofloxacin to achieve serum levels required for effective therapy; however, higher doses could have unwanted clinical and public health consequences. Rather, this in-creased resistance may warrant a restructuring of the chemotherapeutic regimen for enteric diseases, as well as 
restricting use of ciprofloxacin to atypical cases in which lack of clinical response to other therapeutic drugs is noted.

Although water extracts and leaves of Moringa oleifera have been documented to be rich in macro and micro nutrients including manganese, potassium and other essential compounds , water extracts of the plant appear to have no activity intro against clinical isolates of salmonella typhi, this is consistent with the findings of Siddhuraju and Becker (2003) which analyzed the Antioxidant properties of Moringa oleifera and reported that although all leaf extracts were capable of scavenging peroxyl and superoxyl radicals. Similar scavenging activities for different solvent extracts of each collection were found for the stable 1, 1diphenyl 2-picrylhydrazyl ( $\mathrm{DPPH}^{\circ}$ ) radical. Among the three different moringa samples, both methanol and ethanol extracts of Indian origins showed the highest antioxidant activities, 65.1 and $66.8 \%$, respectively, in the $\beta$-carotene-linoleic acid system.

\section{Conclusion}

It should be noted that although ethanol and ether extracts of Moringa oleifera showed some activity $(<10 \mathrm{~mm})$ in vitro against clinical isolates of Salmonella typhi it is comparatively lower than the zone of inhibitions recorded for the different concentration of chloramphenicol $(>19 \mathrm{~mm})$ it is concluded that the antibiotic chloramphenicol is comparatively superior to extracts of Moringa oleifera in the management of infections due to Salmonella typhias indicated.

\section{References}

[1]. Cheesbrough, M., (2000). District laboratory practice in tropical countries. Cambridge University press.pp182-186

[2]. Deeni. Y.Y. and Aishatu M.T (1994) Antimicrobial Susceptibility of Clinical Isolates of Enteric Bacteria in Kano, Nigeria. Orient Journal of Medicine. (1\&2);pp1-4

[3]. Edward, M.J. (1979): Bacterial Susceptibility Testing and Assays in Clinical Diagnosis and management pp. 103-106

[4]. Chandel, D.S., Chaudhry, R., Dhawan, B., Pandey, A. and Dey, A.B., 2000. Drug-resistant Salmonella enterica serotype paratyphiA in India. Emerging infectious diseases, 6(4), p.420.

[5]. Hammer, K.1., Carson, C.F. and Riley, T.V., 2003. Antifungal activity of the components of Melaleuca alternifolia (tea tree) oil. Journal of Applied Microbiology, 95(4), pp.853-860.

[6]. Kita, Hiroshi, and Nikaido Hiroshi. "Structure of Cell Wall Lipopolysaccharide from Salmonella typhimurium IV. Anomeric Configuration of l-Rhamnose Residues and Its Taxonomic Implications". Journal of Bacteriology. 1973. Volume 113. p. 672-679

[7]. Mohammed (1996) Comparative Study of Cassia occidentalis and chloramphenicol .pp 2-21.

[8]. National Committee for Clinical Laboratory Standards. (1997). Methods for Dilution Antimicrobial Susceptibility Tests for Bacteria that Grow Aerobically. Approved Standard M7-A4. NCCLS, Wayne, PA

[9]. Mishra, G., Singh, P., Verma, R., Kumar, S., Srivastav, S., Jha, K. K., \& Khosa, R. L. (2011). Traditional uses, phytochemistry and pharmacological properties of Moringa oleifera plant: An overview. Der Pharmacia Lettre, 3(2), 141-164.

[10]. Pal, S. K., Mukherjee, P. K., Saha, K., Pal, M., \& Saha, B. P. (1995). Antimicrobial action of the leaf extract of Moringa oleifera Lam. Ancient Science of Life, 14(3), 197.

[11]. Prescott LM, Harley JP, Kleen DA (2002). Microbiology, $5^{\text {th }}$ Edition, McGrawHill, NewYork. pp. 774-778 https://en.wikipedia.org/wiki/Moringa_oleifera

[12]. Pal, S.K., Mukherjee, P.K. and Saha, B.P., 1995. Studies on the antiulcer activity of Moringa oleifera leaf extract on gastric ulcer models in rats. Phytotherapy Research, 9(6), pp.463-465.

[13]. Rupali, P., Abraham, O.C., Jesudason, M.V., John, T.J., Zachariah, A., Sivaram, S. and Mathai, D., 2004. Treatment failure in typhoid fever with ciprofloxacin susceptible Salmonella enterica serotype Typhi. Diagnostic microbiology and infectious disease, 49(1), pp.1-3.

[14]. Wain, J., Hoa, N.T., Chinh, N.T., Vinh, H., Everett, M.J., Diep, T.S., Day, N.P., Solomon, T., White, N.J., Piddock, L.J. and Parry, C.M., 1997. Quinolone-resistant Salmonella typhi in Viet Nam: 
Texila International Journal of Medicine

Volume 5, Issue 1, Jun 2017

molecular basis of resistance and clinical response to treatment. Clinical infectious diseases, 25(6), pp.1404-1410. 